\title{
Anna Dymmel
}

Uniwersytet Marii Curie-Skłodowskiej w Lublinie, Polska. Wydział Humanistyczny e-mail a.dymmel@poczta.umcs.lublin.pl

ORCID ID: 0000-0003-3532-3590

rystyna Hudzik, Biblioteki uniwersyteckie w Niemczech w epoce cyfrowej: ciągłość

\section{i zmiana, Warszawa Wydawnictwo SBP,}

\section{Warszawa 2017, ss. 348, il. kolor., ISBN 978-83-65741-01-1}

DOI: http://dx.doi.org/10.12775/FT.2019.014

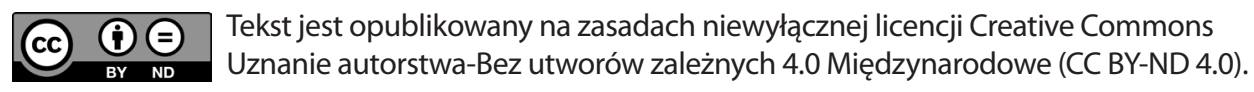

Dr hab. Anna Dymmel jest pracownikiem naukowym Instytutu Nauk o Komunikacji Społecznej I Mediach, kierownikiem Zakładu Kultury Informacyjnej i Czytelnictwa we wspomnianym Instytucie. Jej zainteresowania badawcze obejmują przede wszystkim zagadnienia dotyczące społecznego funkcjonowania książki i bibliotek w ujęciu historycznym i współcześnie. Zajmuje się szczególnie problematyką dotyczącą kultury czytelniczej w ujęciu historycznym (XIX w.) i współczesnymi przemianami zachowań czytelników i użytkowników informacji w dobie cyfrowej. Jest autorką monografii i artykułów, m.in. Księgozbiory domowe w Lublinie w pierwszej połowie XIX wieku (Lublin 2013); Czytelnicy - zasoby informacji i wiedzy. Tradycja i przemiany w czasach kultury cyfrowej, red. A. Dymmel, S. D. Kotuła. (Lublin 2017). Autorka jest członkiem Towarzystwa Naukowego w Lublinie.

łowa kluczowe: biblioteki uniwersyteckie; Niemcy; epoka cyfrowa; komunikacja naukowa

treszczenie: Autorka omawia monografię Biblioteki uniwersyteckie w Niemczech w epoce cyfrowej: ciągłość i zmiany napisaną przez Krystynę Hudzik. Recenzentka podkreśla znaczenie publikacji prezentującej możliwie szeroko i kompleksowo obraz niemieckich bibliotek uniwersyteckich w ujęciu systemowym i dynamicznym. Ponadto wskazuje zalety monografii opartej na wnikliwej analizie bogatych materiałów bibliotecznych, analizie piśmiennictwa oraz obserwacjach prowadzonych w trakcie licznych naukowych pobytów w niemieckich bibliotekach uniwersyteckich i ośrodkach badawczych. Autorka zwraca także uwagę na ogólniejsze rozważania dotyczące perspektyw i roli bibliotek we współczesnej komunikacji naukowej doby cyfrowej. 
Na omawianą monografię wydaną w serii „Nauka-Dydaktyka-Praktyka” przez Wydawnictwo Stowarzyszenia Bibliotekarzy Polskich warto zwrócić uwagę z kilku powodów. Autorka podjęła temat doskonale wpisujący się w ogólniejsze aktualne dyskusje o roli bibliotek uniwersyteckich i ich znaczeniu w komunikacji naukowej doby cyfrowej. Jest to także dobra okazja poznania procesów, jakie zachodziły i zachodzą w bibliotekarstwie w kraju o szczególnie wysokim potencjale ekonomicznym i rozwiniętym systemie bibliotecznym, stanowiącym niejednokrotnie punkt odniesienia dla innych państw. Bibliotekarstwo niemieckie dostarcza przykładów rozwiązań wprowadzanych także w polskich bibliotekach, stąd też niniejsza książka może stać się szczególnie przydatną lekturą. Przedmiotem zainteresowania stały się biblioteki uniwersyteckie w Niemczech od momentu zjednoczenia 3 października 1990 r. do czasów współczesnych, ze szczególnym położeniem nacisku na aktualne zmiany wynikające $z$ globalnych oddziaływań w kontekście lokalnych uwarunkowań. Warto przy tym zauważyć, że jest to jedna z nielicznych prac w polskim piśmiennictwie podejmujących w tak całościowym i systematycznym ujęciu temat bibliotek zagranicznych współcześnie ${ }^{1}$. Co istotne, praca stanowi rezultat solidnych studiów i krytycznej analizy materiałów bibliotecznych, literatury przedmiotu, jak i jest efektem licznych staży i pobytów badawczych Autorki w znanych niemieckich i austriackich bibliotekach oraz instytucjach naukowych. Przypomnę, że w latach 2000-2016 K. Hudzik odbyła staże w bibliotekach uniwersyteckich m.in. w Jenie, Kolonii, Tybindze, Konstancji, Karslruhe i Wiedniu.

Przedmiotem zainteresowania Autorki stały się biblioteki uniwersyteckie ośrodków o różnym potencjale naukowym, niemniej należy podkreślić, że wśród tych około stu placówek są również wysoko notowane w światowych rankingach. W pracy zostały postawione kluczowe dla środowiska bibliotekarskiego i naukowego pytania, jak biblioteki uniwersyteckie w dobie Internetu i Open Access mają zachować swoją istotną rolę w komunikacji naukowej i utrzymać pozycję ważnej jednostki uniwersytetu. Tym samym K. Hudzik prowadzi dociekania zasadnicze dla całego bibliotekarstwa uniwersyteckiego, bo dotyczące przedefiniowania dotychczasowych zadań i określenia nowych ról bibliotek uniwersyteckich. Kwestie te są godne uwagi nie tylko z punktu widzenia bibliotek uczelnianych, ale i całego uniwersytetu. Celem pracy było przedstawienie całościowego obrazu niemieckich bibliotek uniwersyteckich w ujęciu systemowym i dynamicznym i należy przyznać, że cel został spełniony.

Autorka poddała wnikliwej analizie system niemieckich bibliotek uniwersyteckich, ukazała specyfikę systemu bibliotecznego, sposoby i efekty wprowadzania nowych rozwiązań w obszarze organizacji i zarządzania w dobie cyfrowej. Zwróciła uwagę na szczegółowe kwestie dotyczące gromadzenia, udostępniania, roli nowych

M.in. Z. Gruszka, Książka, czytelnik i biblioteka w Stanach Zjednoczonych. Szkic do wizerunku bibliotekarstwa amerykańskiego, [w:] Ludzie i książki: studia i szkice bibliologiczno-bibliograficzne: księga pamiątkowa dedykowana Profesor Hannie Tadeusiewicz, red. E. Andrysiak, przy współ. J. Konieczna, A. Walczak-Niewiadomska, M. Rzadkowolska, Łódź 2011, 193-202; E. Amghar, Infrastruktura informatyczna nowoczesnej biblioteki: co niemieckie biblioteki akademickie oferują swoim czytelnikom?, [w:] Biblioteka akademicka. Infrastruktura - uczelnia - otoczenie, Gliwice, 24-25 października 2013 r., red. M. Odlanicka-Poczobutt, K. Zioło, Gliwice 2014, s. 9-30; Z. Gębołyś, Kształcenie bibliotekarzy dyplomowanych w nowych krajach związkowych RFN - model lipski, Studia Bibliologiczne, t. 13: 2001, s. 22-33; idem, Zespołowa organizacja pracy (teamwork) w niemieckich bibliotekach uniwersyteckich, Biblioteka, t. 12 (21): 2008, s. 129-145. 
technologii, dzięki czemu jest to doskonała lektura dla wszystkich zainteresowanych uniwersytetem, bibliotekami uniwersyteckimi oraz komunikacją naukową i cyfryzacją. Autorka świadoma ogólnych światowych trendów, ukazała przemiany i przekształcenia dotychczasowego tradycyjnego niemieckiego systemu bibliotecznego w szerszym kontekście procesów globalizacyjnych i przemian technologicznych.

K. Hudzik, zgodnie z tytułem książki, skupiła się na ukazaniu aktualnych problemów i rozwiązań typowych dla epoki cyfrowej. Niemniej, chcąc ukazać specyfikę wybranego systemu bibliotek uniwersyteckich niejednokrotnie odwoływała się do przemian mających miejsce w pierwszych latach po zjednoczeniu Niemiec i po II wojnie światowej, które również wywarły istotny wpływ na obecny kształt bibliotekarstwa w ojczyźnie Gutenberga.

Szczegółowe problemy badawcze wytyczają konstrukcję pracy. Wśród podjętych zagadnień znalazło się w pierwszej kolejności nakreślenie systemu bibliotek naukowych oraz usytuowanie bibliotek uniwersyteckich we wspomnianym systemie, następnie charakterystyka stanu prawno-politycznego bibliotek w ramach infrastruktury naukowo-badawczej. Pojawiły się także przykłady współpracy niemieckich bibliotek uniwersyteckich, ponadto oddzielny problem dotyczył struktur organizacyjnych wybranych bibliotek i oceny ich efektywności. Nie zabrakło ważnych pytań o wyzwania, przed jakimi stoją biblioteki uniwersyteckie i charakterystyki wprowadzanych rozwiązań mających na celu dostosowanie się do aktualnych wymogów. Zgodnie z przyjętymi założeniami monografia składa się z pięciu rozdziałów poprzedzonych obszernym wstępem, zakończenia i bibliografii.

Wprowadzenie do tych aktualnie intrygujących środowisko bibliotekarskie zagadnień stanowiło krótkie przypomnienie historii niemieckiego systemu bibliotek naukowych począwszy od lat powojennych, poprzez lata 90. XX w. związane z łączeniem systemów bibliotecznych zjednoczonych Niemiec, po czasy współczesne. Autorka ponadto przedstawiła złożony system niemieckich bibliotek naukowych, przy czym scharakteryzowała Niemiecką Bibliotekę Naukową, Bawarską Bibliotekę Państwową, Bibliotekę Państwową w Berlinie, biblioteki regionalne, biblioteki badawcze i centralne specjalistyczne, biblioteki uniwersyteckie. Zwróciła uwagę na specyficzne historyczne, polityczne, prawne uwarunkowania aktualnego kształtu niemieckiego systemu bibliotek naukowych, na który składają się nie tylko biblioteki uniwersyteckie, lecz także jednostki, jak dowodzą powyższe przykłady, pełniące funkcje bibliotek państwowych, krajowych i miejskich.

Inne aspekty funkcjonowania systemu niemieckich bibliotek naukowych zostały ukazane m.in. w kontekście organizacji nauki i szkolnictwa wyższego w Niemczech z uwzględnieniem również pozauniwersyteckich instytucji naukowych. W tej części Autorka wyjaśniła zawiłości specyficznych dla Niemiec uwarunkowań polityczno-prawnych funkcjonowania systemów bibliotecznych szkół wyższych. Ponadto omówiła politykę prowadzoną wobec szkolnictwa wyższego realizowaną na czterech poziomach: ponadnarodowym (globalnym i europejskim), narodowym, regionalnym i lokalnym, kształtujących model organizacji i zarządzania współczesną uczelnią i nauką. Jednocześnie nie pominęła specyfiki niemieckiego systemu bibliotecznego, zwracając uwagę na charakterystyczne regulacje przyjęte w ustawodawstwie 
niemieckim w tym zakresie. K. Hudzik podkreśliła obecne powszechne tendencje łączenia bibliotek $z$ innymi jednostkami w jedno uniwersyteckie centrum informacji w związku z nowymi ważnymi zadaniami m.in. tworzeniem repozytoriów uczelnianych, publikowaniem elektronicznym i Open Access. Na pewno są to znaczące kwestie, szczególnie w kontekście poszerzenia tradycyjnych obszarów działalności bibliotek i skoncentrowaniu się na zadaniu pośredniczenia w dostępie do informacji.

Krystyna Hudzik zasygnalizowała dylematy stosowania prawa autorskiego i możliwości finansowania działalności szczególnie znaczące dla sprawnego funkcjonowania bibliotek i skutecznej realizacji podejmowanych zadań. Równocześnie Autorka przedstawiła rozważania dotyczące dalszego kierunku rozwoju bibliotek i chociaż trudno jednoznacznie przewidzieć szczegółowe rozwiązania w dłuższej perspektywie, pewne tendencje wyraźnie się rysują. Przede wszystkim zwróciła uwagę na przemiany w obszarze polityki gromadzenia. Podkreśliła stosowaną obecnie w gromadzeniu zasadę skupienia się na aktualnych potrzebach i rzeczywistym wykorzystaniu zasobów racjonalną w dobie gwałtownego przyrostu dokumentów naukowych. Następnie zaakcentowała coraz lepiej widoczną personalizację przekazywania informacji i wynikające stąd nowe rozwiązania organizacyjne ( $w$ tym relacje: jednostka centralna a jednostki wydziałowe). Autorka ponadto wskazała na potrzebę wykorzystania i znaczenie mediów społecznościowych w dzieleniu się wiedzą oraz zalety wykorzystania przez biblioteki narzędzi globalnej pajęczyny w popularyzacji wiedzy².

Z pewnością interesującą lekturę stanowi rozdział trzeci, w którym zostały omówione zagadnienia sieci i kooperacji oraz projekty realizowane przez biblioteki niemieckie. Godną polecenia lekturą jest część poświęcona prezentacji licznych przykładów sprawnie tworzonych nowych form współpracy wynikających z obecnych potrzeb epoki cyfrowej, a dotyczących wszystkich aspektów bibliotecznej działalności począwszy od gromadzenia, opracowania, a na udostępnianiu i digitalizacji kończąc. W pracy znalazły się interesujące przykłady projektów związanych z gromadzeniem zbiorów, uwagę zwróciły zasady dotyczące rozwijania zbiorów zagranicznych, głównie zasobów elektronicznych. Na pewno istotną rolę w funkcjonowaniu środowiska i podejmowaniu wspólnych inicjatyw, co warto podkreślić, odgrywają organizacje biblioteczne i zrzeszenia bibliotekarzy, o czym także pisała Autorka.

Poza gromadzeniem, współpraca oczywiście obejmuje inne obszary działalności bibliotecznej, tj. opracowanie i przykłady tego typu działań także zostały opisane. Niemieckie biblioteki w chmurze, jak dowodzi Autorka, to nie tylko hasło. Jak pokazują zebrane doświadczenia przede wszystkim innowacje wiązały się z przechodzeniem na systemy biblioteczne nowej generacji na bazie Cloud. Podobnie K. Hudzik omówiła nowe formy współpracy w zakresie udostępniania, zwróciła także uwagę na dokonania dotyczące systemowo prowadzonej digitalizacji bogatego dorobku obszaru niemieckiego, doskonale wpisujące się w potrzeby zachowania dziedzictwa kulturowego. Podsumowanie rozdziału stanowią rozważania poświęcone nowym trendom komunikacji naukowej, roli mediów społecznościowych, nowym

\footnotetext{
2 G. Piotrowicz, Współczesna biblioteka akademicka w ujęciu systemowym, integrującym jej przestrzeń fizyczną i wirtualną, Biuletyn EBIB [online] 2015, nr 155 (1) [dostęp 30 IV 2019]. Dostępny w World Wide Web: http://open. ebib.pl/ojs/index.php/ebib/article/view/321.
} 
typom publikacji i danych w kontekście roli bibliotek. Otwarte pozostaje pytanie na ile te nowe możliwości zostaną wykorzystane i pozwolą bibliotekom podążać za użytkownikami?

Konsekwentnie realizując wytyczone cele rozprawy, Autorka podjęła w przedostatnim rozdziale zagadnienia dotyczące specyfiki organizacji i zarządzania biblioteką, na wybranych przykładach. Z uwagi na bogactwo zagadnień skoncentrowała się na ukazaniu przemian organizacji bibliotek w związku z potrzebami efektywnego zarządzania i na zmianach strukturalnych wynikających z nowych zadań i reorientacji usług skupiających się przede wszystkim na potrzebach użytkowników. Opisała trafnie wybrane przykłady bibliotek położonych na obszarach różnych landów, ale posiadających bogate zbiory i o licznych udostępnieniach, tj. Bibliotekę Uniwersytetu Humboldta w Berlinie, Bibliotekę Uniwersytecką i Miejską w Kolonii oraz Bibliotekę Uniwersytecką i Krajową Turyngii w Jenie. Obserwacje prowadzone we wskazanych bibliotekach ukazują m.in. spłaszczenie struktur, łączenie gromadzenia i opracowania mediów (co jest powszechne i w innych bibliotekach), ukazują ważną pozycję bibliotekarzy dziedzinowych i niektóre inne rozwiązania specyficzne dla niemieckich bibliotek. Uwagę zwracają także rozważania K. Hudzik dotyczące wprowadzania nowych rozwiązań organizacyjnych niejednokrotnie wywodzących się z instytucji komercyjnych, czyli zrównoważonej karty wyników (wywodzącej się z mierzenia wydajności i wyników przedsiębiorstw) oraz popularne zarządzanie jakością. Korzystając z doświadczeń z wprowadzenia tego typu koncepcji, również biblioteki niemieckie z powodzeniem stosują powyższe rozwiązania. Autorka zwróciła uwagę na praktykę stosowania tychże systemów zarządzania, w tym elastyczne podejście i systematyczną ewaluację, bieżące korekty z punktu widzenia ich efektywności, co może być inspirujące dla innych bibliotek zmierzających do optymalizacji swej struktury ${ }^{3}$.

Nie pominęła Autorka istotnych zagadnień interesujących wszystkich bibliotekarzy, a dotyczących pracowników bibliotek. Zachodzące zmiany, jak sygnalizowała, wymuszają zmiany kompetencyjne i kadrowe wynikające z nowych reguł organizacyjnych i reorientacji zadań. Zwróciła uwagę na system dziedzinowych referentów i usług informacyjnych, w tym na przekształcenia ról i kompetencji pracowników bibliotek - przede wszystkim bibliotekarzy naukowych (specjalistów dziedzinowych, bibliotekarzy dziedzinowych). Na pewno powyższe kwestie są szczególnie ważne i również moim zdaniem zasługują na rozwinięcie. Z pewnością będą jeszcze niejednokrotnie przedmiotem zainteresowania samej Autorki i środowiska bibliotekarskiego.

Odrębne podrozdziały zostały poświęcone problemom gromadzenia, przede wszystkim w aspekcie ekonomicznym, jak i w kontekście gwałtownego przyrostu informacji oraz potrzeb użytkowników. Nowe modele gromadzenia nastawione na optymalizację gospodarowania funduszami bibliotecznymi i zwiększenie stopnia wykorzystania zbiorów bibliotecznych z pewnością wymagają systematycznej ewaluacji, o czym pisała autorka, zamykając omawiane zagadnienie.

Szczególnie ciekawą lekturą jest ostatni rozdział poświęcony aktualnym tematom bibliotecznym, istotny dla wszystkich zainteresowanych perspektywami i rolą bibliotek

S. Hurst, Current trends in UK University libraries, New Library World, vol. 114:2013, nr 9, s. 398-407. 
uniwersyteckich w epoce cyfryzacji oraz możliwościami wpisania się w aktualne trendy i potrzeby komunikacji naukowej. Zagadnienia przyszłości bibliotek w dobie e-Science pojawiały się, jak wspominałam, już przy okazji omawiania wybranych kwestii, w tym rozdziale jednak znalazły systematyczne rozwinięcie. Biblioteki uczelniane muszą się zmierzyć z problemami otwartego dostępu (OA), publikowaniem elektronicznym, problemem danych badawczych, archiwizacją i długoterminową dostępnością danych cyfrowych. Co oczywiste, problemy te są uniwersalne i szczególnie intrygujące dla wszystkich zainteresowanych bibliotekami uczelnianymi. Chociaż idea Open Access zmierzająca do powszechnego i swobodnego dostępu do naukowych i edukacyjnych treści cyfrowych pozostaje w znacznej rozbieżności do oczekiwań wydawców ${ }^{4}$, to jednak biblioteki również w tym zakresie podejmują działania zmierzające do pogodzenia sprzecznych interesów. Otwarte pozostaje pytanie, jaką faktycznie rolę odegrają biblioteki w kontekście dalszego rozwoju technologii i OA ${ }^{5}$.

Warto także zwrócić uwagę na rozważania dotyczące tworzenia repozytoriów uczelnianych. Autorka przedstawiła wybrane przykłady, omówiła niemieckie doświadczenia w tym zakresie, uwzględniając warunki techniczne, organizacyjne oraz finansowe.

Interesujący kierunek obecnych działań bibliotek, jak dowodzi Autorka, stanowi także publikacyjna działalność, dotychczas niejednokrotnie pozostająca nieco na uboczu, a obecnie stwarzająca nowe możliwości poszerzenia obszarów działalności bibliotecznej. Oczywiście dotychczas przynajmniej część bibliotek podejmowała działalność edytorską, na co już zwracali uwagę badacze ${ }^{6}$ niemniej dla wielu placówek nowym doświadczeniem będzie produkcja publikacji, szczególnie elektronicznych. Biblioteki niemieckie mogą pochwalić się już dokonaniami na tym polu, co ma szczególne znaczenie dla przejęcia roli centralnego portalu informacyjnego uczelni.

Niewątpliwie obecnie żywo dyskutowanym problemem jest postępowanie z danymi badawczymi i dobrze się stało, że Autorka podjęła ten wątek ${ }^{7}$. W tym nowym obszarze na razie większymi doświadczeniami praktycznymi mogły wykazać się przede wszystkim niemieckie uniwersytety medyczne i techniczne. Autorka przedstawiła stosowane rozwiązania i tworzone standardy, chociaż jest świadoma dynamiki zjawiska i trudności w prognozowaniu zmian nawet w nieodległej przyszłości. Niemniej szybkie tempo rozwoju wymusza także podejmowanie działań w tej sferze przez inne naukowe biblioteki ${ }^{8}$. Na pewno także ważnym wyzwaniem dla naukowych bibliotek jest długoterminowa dostępność i archiwizacja źródeł cyfrowych. Również na tej płaszczyźnie biblioteki uniwersyteckie podjęły prace i autorka dzieli się dotychczasowymi doświadczeniami z tego obszaru. Na pewno lektura opisu

\footnotetext{
4 B. Bednarek-Michalska, Biblioteki cyfrowe (repozytoria) - nową ofertą usługową dla naukowych środowisk medycznych w Polsce [online], [dostęp 30 III 2019]. Dostępny w World Wide Web: http://konferencja.biblio.cm.umk.pl/fileadmin/ pelne_teksty/Bednarek-michalska.doc.

5 M. J. Mc Cabe, Ch.M. Snyder, A. Fagin, Open Access versus Traditional Journal Pricing: Using a Simple "Platform Market" Model to Understand Which Will Win (and Which Should), The Journal of Academic Libraries, vol. 39: 2013, nr 1, s. 11-19.

6 N. Canty, Libraries as publishers: turning the page, Alexandria, Vol 23: 2012, nr 1, s. 56-62; J. Wojciechowski, Biblioteka akademicka jako wydawca, [w:] Działalność wydawnicza bibliotek w czasach konwergencji mediów, red. W. S. Wojnarowicz, B. Kasperek, Lublin 2002, s. 13-20.

7 C. Tenopir, S. Talja, W. Horstmann, E. Late, D. Hughes, D. Pollock, B. Schmidt, L. Baird, R. Sandusky, S. Allard, Research data services in European academic research libraries, LIBER Quarterly, vol. 21: 2017, s. $23-44$.

8 M. Kamińska, Dobre praktyki publikowania danych badawczych, Biuletyn EBIB [online], 2017, nr 177 (1) [dostęp 30 IV 2019]. Dostępny w World Wide Web: http://open.ebib.pl/ojs/index.php/ebib/article/view/569/752.
} 
znanych praktyk niemieckich bibliotek dostarcza ciekawych przykładów działań pozwalających wpisać się bibliotekom w oczekiwania epoki cyfrowej i zachować znaczącą rolę w systemie naukowej komunikacji i w uczelnianym systemie.

Monografię zamykają Uwagi na zakończenie zawierające syntetyczne wnioski. Autorka doskonale znająca realia niemieckiego bibliotekarstwa, podkreśla konsekwentną politykę biblioteczną państwa, współpracę bibliotek z naukowcami, systematyczne wprowadzanie innowacji w tradycyjnych obszarach działalności bibliotecznej związanych z gromadzeniem, opracowaniem, oraz podejmowanie nowych wyzwań. Doskonalenie efektywności pracy bibliotek, rozwijanie kooperacji, digitalizacja zasobów historycznych, publikowanie elektroniczne, zarządzanie informacją w dobie Open Access pozwalają myśleć z nadzieją o przyszłości bibliotek. Odpowiedź Autorki na postawione we wstępie pytanie czy biblioteki mogą odegrać istotną rolę w dobie Internetu, jest twierdząca.

Z pewnością, jak zasygnalizowała K. Hudzik tematy dotyczące bibliotek uniwersyteckich warto kontynuować. Szczególne na rozwinięcie, z czym trzeba się zgodzić, zasługują m.in. zagadnienia dotyczące potrzeb i obsługi użytkowników ${ }^{9}$, personalizacja usług, rozwijanie usług elektronicznych. Na pewno uwagi wymagają kwestie edukacji informacyjnej użytkowników, popularyzacja wiedzy ${ }^{10}$, czy problemy odpowiedniej aranżacji przestrzeni i architektury bibliotecznej pozwalających na efektywne wykorzystanie istniejących możliwości ${ }^{11}$. Należałoby także, jak zaznaczyła Autorka, rozważyć sposobność wykorzystania bibliotek w pozyskiwanie treści przydatnych w e-learningu we współpracy z naukowcami. Biblioteka ucząca i idea biblioteki jako miejsca uczenia się doskonale sprawdzają się w Niemczech, dowodząc żywotności i znaczenia bibliotek w środowisku uniwersyteckim. Obszerna bibliografia zawiera wykaz wykorzystanych bogatych materiałów oraz imponujące zestawienie wykorzystanych opracowań. Praca została zaopatrzona w streszczenie w języku niemieckim. Szkoda natomiast, mając na uwadze szerszy odbiór, że wydawnictwo nie zadbało o dołączenie streszczenia w języku angielskim, zadowalając się jedynie spisem treści w tymże języku. Dobre uzupełnienie książki stanowią zamieszczone na końcu zdjęcia bibliotek pochodzące ze zbiorów autorki.

Niewątpliwą zaletą monografii jest szczególna aktualność podejmowanych kwestii, wieloaspektowość i wnikliwość prowadzonych analiz, systematyczność wykładu. W klarowny i przejrzysty sposób praca przybliża czytelnikom szereg zagadnień dotyczących niemieckich bibliotek uniwersyteckich. Diagnozie wybranego systemu bibliotek uczelnianych towarzyszy świadomość globalnych trendów, szczególnie oddziaływania bibliotekarstwa amerykańskiego. Przydatne są także rozważania

\footnotetext{
U. Kulczycka, Czy można studiować bez biblioteki? Diagnoza problemu w oparciu o badania przeprowadzone wśród studentów Uniwersytetu Gdańskiego, [w:] Biblioteki bez użytkowników...? Diagnoza problemu. V Ogólnopolska Konferencja Naukowa, Supraśl 14-16 września 2015, red. H. Brzezińska-Stec, J. Żochowska, Białystok 2015, s. 229-242.

10 M. Janas, Popularyzowanie wiedzy naukowej i upowszechnianie kultury w bibliotece akademickiej, Bibliotheca Nostra, t. 27: 2012, nr 1, s. 52-64.

11 M.in. D. Konieczna, Współczesne trendy architektury bibliotecznej a zmieniające się wymagania użytkowników, [w:] Biblioteki XXI wieku. II Konferencja Politechniki Łódzkiej, Łódź 19-21 czerwca 2006: materiały konferencyjne, Łódź 2006, s. 217-228; J. Sykes, Redeveloping the World's largest Social Science Library for the 21st century, LIBER Quarterly [online], 2004, vol. 14, nr 2 [dostęp 30 IV 2019]. Dostępny w World Wide Web: http://doi.org/10.18352/ lq.7761.
} 
ukazujące konkretne rozwiązania pozwalające dostosować ogólniejsze tendencje do lokalnych potrzeb. Chociaż szczegółowe recepty wymagałyby oddzielnego rozwinięcia, wiele zastosowań może być inspirujące również dla polskich bibliotek akademickich. Walorem rozprawy jest ponadto umiejętne łączenie teorii z praktyką, zwrócenie uwagi na nowoczesne rozwiązania, dzięki czemu jest to niewątpliwie znaczący głos w dyskusjach nad bibliotekami akademickimi również w rodzimym kontekście ${ }^{12}$.

Omawiana monografia, włączając się w rozważania nad współczesnymi bibliotekami uniwersyteckimi, ukazuje rolę i potencjał bibliotek w kreowaniu kanałów nowoczesnej komunikacji naukowej. Istotne są ogólniejsze refleksje dotyczące perspektyw rozwoju placówek, stałej potrzeby wprowadzania innowacji i szybkiej rekcji na sygnały otoczenia. Rozprawa stanowi szczególnie interesującą lekturą, godną polecenia dla bibliotekarzy uniwersyteckich i pracowników innych bibliotek naukowych, którzy mogą skonfrontować własne doświadczenia zawodowe z tym co dzieje się za zachodnią granicą. Z pewnością jest także przydatnym opracowaniem dla potencjalnych bibliotekarzy i zajmujących się kształceniem kadr dla nowoczesnych bibliotek oraz ośrodków informacji. Ponadto, co należy podkreślić, będzie pozytywnym impulsem dla wszystkich zainteresowanych aktualnymi ogólniejszymi trendami rozwoju komunikacji naukowej i uniwersytetów, badaniami, a także ich popularyzacją w dobie mediów cyfrowych.

\section{Bibliografia}

Amghar, Ewa. 2014. „Infrastruktura informatyczna nowoczesnej biblioteki: co niemieckie biblioteki akademickie oferują swoim czytelnikom?" W Biblioteka akademicka. Infrastruktura - uczelnia - otoczenie, Gliwice, 24-25 października 2013 r., red. M. Odlanicka-Poczobutt, K. Zioło, 9-30. Gliwice: Wydawnictwo Politechniki Śląskiej.

Bednarek-Michalska, Bożena. 2008. „Biblioteki cyfrowe (repozytoria) - nową ofertą usługową dla naukowych środowisk medycznych w Polsce." dostęp Marzec 30 http://konferencja.biblio.cm.umk.pl/fileadmin/pelne_teksty/Bednarek-michalska.doc.

Canty, Nick. 2012. „Libraries as publishers: turning the page.” Alexandria, 23 (1): 56-62.

Gębołyś, Zdzisław. 2001. „Kształcenie bibliotekarzy dyplomowanych w nowych krajach związkowych RFN - model lipski." Studia Bibliologiczne, 13: 22-33.

Gębołyś, Zdzisław. 2008. „Zespołowa organizacja pracy (teamwork) w niemieckich bibliotekach uniwersyteckich." Biblioteka, 12 (21): 129-145.

Gruszka, Zbigniew. 2011. „Książka, czytelnik i biblioteka w Stanach Zjednoczonych. Szkic do wizerunku bibliotekarstwa amerykańskiego." W Ludzie i książki: studia i szkice bibliologiczno-bibliograficzne: księga pamiątkowa dedykowana Profesor Hannie Tadeusiewicz, red. E. Andrysiak, przy współ. J. Konieczna, A. Walczak-Niewiadomska, M. Rzadkowolska,193-202. Łódź: Wydawnictwo Uniwersytetu Łódzkiego.

\footnotetext{
12 H. Hollendr, Nauka jako mrowisko: miejsce biblioteki w sieciach współpracy badawczej. Prezentacja z XVIII Ogólnopolskiej konferencji naukowej bibliotek uczelni niepublicznych i publicznych organizowanej przez Bibliotekę Wyższej Szkoły Biznesu - National-Louis University w Nowym Sączu w dn. 24-25.05.2018 r. pt. „Biblioteka przyszłości - wyzwania - trendy - zagrożenia”. Sesja II [online], [dostęp 30 III 2019]. Dostępny w World Wide Web: http://hdl.handle.net/11199/10406.
} 
Hollendr, Henryk. 2018. „Nauka jako mrowisko: miejsce biblioteki w sieciach współpracy badawczej. Prezentacja z XVIII Ogólnopolskiej konferencji naukowej bibliotek uczelni niepublicznych i publicznych organizowanej przez Bibliotekę Wyższej Szkoły Biznesu - National-Louis University w Nowym Sączu w dn. 24-25.05.2018 r. pt. Biblioteka przyszłości - wyzwania - trendy - zagrożenia. Sesja II." Dostęp Marzec 30 http://hdl.handle.net/11199/10406.

Hurst, Susan. 2013. „Current trends in UK University libraries.” New Library World, 114 (9): 398-407.

Janas, Magdalena. 2012. „Popularyzowanie wiedzy naukowej i upowszechnianie kultury w bibliotece akademickiej.” Bibliotheca Nostra, 27 (1): 52-64.

Kamińska, Anna M. 2017. „Dobre praktyki publikowania danych badawczych.” Biuletyn EBIB, 177 (1). Dostęp Kwiecień 30, http://open.ebib.pl/ojs/index.php/ebib/ article/view/569/752.

Konieczna, Danuta. 2006. „Współczesne trendy architektury bibliotecznej a zmieniające się wymagania użytkowników." W Biblioteki XXI wieku. Czy przetrwamy? II Konferencja Politechniki Łódzkiej, Łódź 19-21 czerwca 2006: materiały konferencyjne, red. B. Feret at al., 217-228. Łódź: Wydawnictwo Politechniki Łódzkiej.

Kulczycka Urszula. 2015. „Czy można studiować bez biblioteki? Diagnoza problemu w oparciu o badania przeprowadzone wśród studentów Uniwersytetu Gdańskiego." W Biblioteki bez użytkowników...? Diagnoza problemu. V Ogólnopolska Konferencja Naukowa, Supraśl 14-16 września 2015, red. H. Brzezińska-Stec, J. Żochowska, 229-242. Białystok: Wydawnictwo Uniwersytetu w Białymstoku.

Mc Cabe, Marck.J., Snyder, Christopher.M., Fagin, Anna. 2013. „Open Access versus Traditional Journal Pricing: Using a Simple "Platform Market" Model to Understand Which Will Win (and Which Should)." The Journal of Academic Libraries, 39 (1): 11-19.

Piotrowicz, Grażyna. 2015. „Współczesna biblioteka akademicka w ujęciu systemowym, integrującym jej przestrzeń fizyczną i wirtualną." Biuletyn EBIB, 155 (1). Dostęp Kwiecień 30. http://open.ebib.pl/ojs/index.php/ebib/article/view/32.

Sykes, Jean. 2004. „Redeveloping the World's largest Social Science Library for the 21st century." LIBER Quarterly, 14 (2). Dostęp Kwiecień 30. DOI: http://doi. org/10.18352/lq.7761.

Tenopir, Carol. Talja, Sanna. Horstmann, Wolfram. Late, Elina. Hughes, Dane. Pollock, Danielle. Schmidt, Birgit. Baird, Lynn. Sandursky, Robert. Allard, Suzie. 2017. „Research data services in European academic research libraries.” LIBER Quarterly, 21 (1): 23-44.

Wojciechowski, Jacek. 2002. „Biblioteka akademicka jako wydawca.” W Działalność wydawnicza bibliotek w czasach konwergencji mediów, red. W. S. Wojnarowicz, B. Kasperek, 13-20. Lublin: Wydawnictwo Uniwersytetu Marii Curie-Skłodowskiej. 


\section{Anna Dymmel}

Maria Curie-Sklodowska University, Poland. Faculty of Political Science and Journalism

e-mail a.dymmel@poczta.umcs.lublin.pl

ORCID ID: 0000-0003-3532-3590

Dr hab. Anna Dymmel is a researcher at the Institute of Social Communication and Media Sciences in Lublin, head of the Department of Information Culture and Reading at the above mentioned Institute. Her research interests include primarily issues related to the social functioning of books and libraries in historical and contemporary terms. She particularly deals with issues related to reading culture in the historical perspective (the $19^{\text {th }}$ century) and contemporary changes in the behaviour of readers and users of information in the digital age. She is the author of monographs and articles, including Home book collections in Lublin in the first half of the $19^{\text {th }}$ century (Lublin 2013); Readers - information and knowledge resources. Tradition and changes during the digital culture, edited by A. Dymmel, S. D. Kotuła. (Lublin 2017). The author is a member of the Scientific Society in Lublin.

\section{Krystyna Hudzik, University libraries in}

\section{Germany in the digital age: continuity and}

\section{change, Warszawa Wydawnictwo SBP}

\section{Warsaw 2017, pp. 348, illustration color., ISBN 978-83-65741-01-1}

DOI: http://dx.doi.org/10.12775/FT.2019.014

(c) $\bigodot_{\mathrm{BY}} \bigodot_{\mathrm{ND}}$ The text is available under a Creative Commons Attribution-NoDerivatives 4.0 International (CC BY-ND 4.0).

eywords: university libraries; Germany; the digital age; scientific communication

ummary: The aim of the text is to discuss the monograph University Libraries in Germany in the digital age: continuity and change written by Krystyna Hudzik. The author emphasizes the importance of the publication presenting the widest possible and comprehensive picture of German university libraries in a systemic and dynamic approach. In addition, she indicates the advantages of a monograph based on a thorough analysis of rich library materials, analysis of literature and observations conducted during her numerous scientific stays in German university libraries and research centres. The author also draws attention to general considerations regarding the perspectives and role of libraries in contemporary scientific communication of the digital age. 


\section{Anna Dymmel}

Maria-Curie-Skłodowska-Universität, Polen. Fakultät für Politikwissenschaft und Journalismus

e-mail a.dymmel@poczta.umcs.lublin.pl

ORCID ID: 0000-0003-3532-3590

Dr. habil. Anna Dymmel ist Dozentin am Institut für Soziale Kommunikation und Medienwissenschaften in Lublin, Leiterin der Abteilung für Informations- und Lesekultur daselbst. In ihr Forschungsinteresse fallen vor allem die sozialen Funktionen von Buch und Bibliotheken aus historischer und moderner Sicht. Sie beschäftigt sich mit den aus historischer Sicht analysierten Fragen der Lesekultur (19. Jahrhundert) und dem heutigen Wandel in der Haltung der Leser und Informationsbenutzer im digitalen Zeitalter. Sie ist Autorin von Monografien und Artikeln, darunter Księgozbiory domowe w Lublinie w pierwszej połowie XIX wieku (Lublin 2013; Die Privatbuchbestände in Lublin in der ersten Hälfte des 19. Jahrhunderts); Czytelnicy - zasoby informacji i wiedzy. Tradycja i przemiany w czasach kultury cyfrowej, red. A. Dymmel, S. D. Kotuła. (Lublin 2017; Leser - Informations- und Wissensbestände. Tradition und Wandel in der Zeit der digitalen Kultur). Die Autorin ist Mitglied der Wissenschaftlichen Gesellschaft zu Lublin.

\section{Krystyna Hudzik, Universitätsbibliotheken in Deutschland im digitalen Zeitalter.}

\section{Kontinuität und Wandel, Warszawa}

\section{Wydaw nictwo SBP, Warszawa 2017, SS. 348, Abb. farb., ISBN 978-83-65741-01-1}

DOI: http://dx.doi.org/10.12775/FT.2018.014

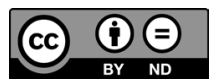

Dieser Text wird unter der Creative Commons-Lizenz Namensnennung-Keine Bearbeitungen 4.0 International (CC BY-ND 4.0) veröffentlicht.

tichworte: Universitätsbibliotheken; Deutschland; digitales Zeitalter; wissenschaftliche Kommunikation

usammenfassung: Der Text zielt auf die Besprechung der Monografie Biblioteki uniwersyteckie w Niemczech w epoce cyfrowej. ciągłość i zmiany (Universitätsbibliotheken in Deutschland im digitalen Zeitalter. Kontinuität und Wandel), angefertigt von Krystyna Hudzik. Die Autorin betont die Bedeutung der Publikation, die die deutschen Universitätsbibliotheken aus systematischer und dynamischer Sicht möglichst ausführlich schildert. Zudem weist sie auf die Vorteile der Monografie hin, die sich auf eine gründliche Analyse von zahlreichen 
Bibliotheksmaterialien und vom Schrifttum sowie auf Beobachtungen während zahlreicher wissenschaftlicher Aufenthalte in den deutschen Universitätsbibliotheken und Forschungszentren stützt. Die Autorin schildert auch allgemein die Perspektiven und die Rolle von Bibliotheken in der modernen wissenschaftlichen Kommunikation im digitalen Zeitalter. 